\title{
LESSONS FROM HART: A REPLY TO WALUCHOW
}

\author{
Kenneth Einar HIMMA*
}

\section{Resumen:}

En este breve ensayo, intento responder a la crítica de Wilfrid Waluchow sobre mi teoría positivista de la obligación jurídica, crítica que aparece en su colaboración de este número, Lessons from Hart. Waluchow sostiene, con perspicacia y elegancia, que mi teoría fracasa al no distinguir entre el punto de vista interno y externo, y que ofrece una explicación de la obligación jurídica desde el punto de vista externo. Intento refutar esta interesante crítica al argumentar que la distinción entre el punto de vista interno y externo fue hecho dentro del análisis de Hart de los conceptos centrales del derecho y que yo intento proporcionar una explicación desde el mismo punto de vista que toma Hart cuando analiza conceptos jurídicos, el de la metodología tradicional del análisis conceptual.

\section{Palabras clave:}

Obligación, obligación jurídica, normas sociales, punto de vista interno, punto de vista externo.

\section{Abstract:}

In this brief essay, I attempt to reply to Wilfrid Waluchow's critique of my positivist theory of legal obligation, which appear in his contribution to this volume, Lessons from Hart. Waluchow argues, with insight and elegance, that my theory fails to distinguish between the internal and external point of view, and gives an account of legal obligation from the external point of

* himma@uw.edu. 


\section{KENNETH EINAR HIMMA}

view. I attempt to rebut this interesting criticism by arguing that the distinction between the internal and external point of view was made inside Hart's analysis of the concepts central to law, and that I am attempting to give an account from the same point of view that Hart takes when he analyzes legal concepts - that of the methodology of traditional conceptual analysis.

Keywords:

Obligation, Legal Obligation, Social Norms, Internal Point of View, External Point of View. 
SUmmaRY: I. Introduction. II. Waluchow's Critique. III. Reply to Waluchow.

\section{INTRODUCTION}

In his outstanding paper Lessons from Hart, ${ }^{1}$ Wilfrid Waluchow does me the honor of critiquing my attempt to provide a comprehensive positivist account of legal obligation that covers both the rule of recognition that governs the conduct of officials and the primary rules of obligation that bind citizens. ${ }^{2}$ The starting points for my argument are (1) that, as positivism insists, law is a social artifact all the way down; and (2) that, according to Hart, "Rules are conceived and spoken of as imposing obligations when the general demand for conformity is insistent and the social pressure brought to bear upon those who deviate or threaten to deviate is great." 3

The basic idea is that the quote in (2), understood as a conceptual claim about the nature of social obligation, provides an adequate grounding for a comprehensive theory of legal obligation Hart was obliged to give but never did, explaining only the second-order obligations of officials defined by the rule of recognition. Hart accomplished this by recourse to what I take to be his theory of social norms and obligations but, notably, had little to say about the legal obligations of citizens.

This is problematic for two reasons. First, when we talk about the obligations of law in legal practice, we are most often speaking of the legal obligations of citizens generated by the primary legal norms valid under the rule of recognition. This is not to say that the duties defined by certain norms comprising the rule of recognition are not of theoret-

1 Wil Waluchow, "Lessons from Hart", Problema, n. 5, 2011.

2 Kenneth Einar Himma, "A Positivist Theory of Legal Obligation," Problema, n. 5, 2011.

3 H. L. A. Hart, The Concept of Law (Revised ed.) (Oxford: Oxford University Press, 1994), 86. 
ical importance, but Hart notes, correctly, that Austin's basic starting point that law creates obligations is correct and Austin's theory was concerned with the legal obligations of citizens. This means not only that Hart lacks a comprehensive theory of legal obligation, but also arguably ignored the most important part of the problem.

Second, there is an element of unfairness involved. Hart rejected Austin's theory of law partly on the ground that Austin couldn't distinguish a gunman from the state. That is to say, that he found Austin's account of legal obligation confused the notion of being obligated with the notion of being obliged: one is obliged, not obligated, to conform to the commands of a gunman - and the legal system, on Hart's view of Austin, is nothing more than a gunman writ large. According to Hart, Austin had explained no more than how citizens are obliged to comply with the law. It is true that Austin overlooked the rule of recognition and hence lacked an essential piece of the story of legal obligation, believing implausibly that sovereigns were incapable of legal limitation. Nonetheless, it seems unfair, among other things, to reject Austin's account of legal obligation, which applies exclusively to citizens, and not offer something better.

In consequence, Hart lacked a comprehensive theory of the normativity of law, one of the most important problems in conceptual jurisprudence - no matter how it is conceived. Theorists like Jules Coleman believe that it is sufficient to resolve the issue to explain how it is logically possible for law to create obligations -or, otherwise put, make intelligible law's ability to create legal obligations. On his view, law purports to, but often fails, to create legal obligations. ${ }^{4}$ I have challenged this view elsewhere ${ }^{5}$ but, even if

4 Jules Coleman, "Conventionality and Normativity," in Enrique Villanueva (ed.), Legal and Political Philosophy. Social, Political, \& Legal Philosophy, Volume 1, (Amsterdam/New York, NY: 2002).

5 Kenneth E. Himma, "Conceptual Jurisprudence and the Intelligibility of Law's Claim to Obligate," in Michael O'Rourke, Joseph Keim-Campbell, and Harry Silverstein (eds.), Topics in Contemporary Philosophy (Volume III): Law and Social Justice (Boston: MIT Press, 2005). 
this is the correct formulation of the problem of explaining legal normativity, Hart has offered no comprehensive account of even explaining this much.

Of course, as my contribution makes clear, I believe law necessarily creates legal obligations and this is part of the explanation of law's distinctive normativity. The specific thesis of the paper is that the legal obligations of officials in their capacities as officials and the first-order legal obligations of citizens under the primary rules can be explained in terms of Hart's theory of social obligation. ${ }^{6}$ What constitutes the binding force of a secondary rule of recognition on officials (and hence law's distinctive normativity as it applies to officials) is, so to speak, the authorization of social pressure as a response to non-compliance. As for the binding force of legal obligation as it pertains to citizens, it is the authorization - at least in modern municipal legal systems of which we are aware- of coercive enforcement mechanisms that constitutes the binding force of an obligation and provides reasons for acting in accordance with the law.

Now, it is important to note at the outset that the theory of legal obligation I defend does not reduce obligation to the authorization or appropriateness of formal or informal social pressure. There are other conditions that have to be satisfied:

A norm is legally obligatory if and only if (1) it the behaviour it requires is made mandatory (2) by a valid legal norm (in a legal system, of course) (3) that is exclusionary and (4) backed by social pressure (5) because the norm protects what is taken to be a particularly important feature of society.

\footnotetext{
6 It is, I should note, no part of my project as Waluchow makes clear, if I did not, to attribute this thesis to Hart. My project is not an interpretive project. It is charitable of Waluchow to acknowledge this because I think he offers very good reasons to think that my view shouldn't be attributed to Hart - although, as I mentioned, I think there is some reason to think he would have held this view.
} 
My claim in the paper is that it is the authorization of coercive enforcement mechanisms that constitutes a first-order legally valid norm as having the binding force characteristically associated with obligations as a general matter. Moreover, this binding force is a way of describing the distinctive reasons for action that obligations provide. Thus, a first-order legal obligation exists when conditions (1) through (5) are satisfied. But the binding force and special reasons that legal obligations provide are constituted by authorization of coercive enforcement mechanisms.

\section{WALUCHOW'S CRITIQUE}

Waluchow's subtle and important objection to my thesis is that my account fails to overlook the idea that what constitutes the binding force of a legal obligation depends on what point of view we take towards the obligation. As Waluchow puts this insightful objection much more elegantly than I can, I will quote him here:

Let's now consider the following question[].... Under which rules do obligations arise within a community? Put this way, one might naturally answer these questions much as Himma indicates - and go on to conclude that Hart has not, in fact, taken a significant step beyond Austin. [But] here the importance of context comes acutely to the fore because we get very different answers depending on the point of view from which the question is put.

Let's begin with the external, theoretical point of view. On this reading, the question asks how, from the perspective of an external observer of a society and its workings, one could distinguish rules that function as obligation rules from those that do not. Hart's answer, of course, is that we would look to those rules that bear the features he mentions: they require personal sacrifice, are accompanied by serious social pressure and demands for conformity, and there is a widespread belief that these responses are appropriate because 
the rule protects a crucial feature of social life or some highly prized feature of it.....

Now consider [the] question... from the internal point of view, that is from the point of view of one who views the rule as actually providing him and others with sound or valid reasons for action. Will such a person answer [the] question by citing the features Hart describes? Will he cite the serious social pressure to conform and the widespread belief that the rule promotes or protects important values? Of course he won't. He'll cite the important values. From his internal perspective, it's not the serious social pressure that produces the chain that binds, that provides the normative force that Himma seeks. Instead it's the values in light of which such pressure and criticism are believed to be warranted or justified. That the shared social rule is, in his estimation, actually necessary to social life, or some highly prized feature of it, is a good part of the reason why it counts among those rules that actually impose obligations on him. From his perspective, the "existence" of obligation is not a matter of sheer social fact; it is not simply a matter of the right practice conditions being met.... ${ }^{7}$

This subtle and insightful criticism, as I understand it, is that my account of the binding force of an obligation incorrectly takes the external point of view towards the rule, explaining it in terms of a disinterested observer (i.e., one who neither accepts, endorses or supports the legal system or the rule) who sees only that the rule generating the obligation is supported by some form of social pressure. The disinterested observer does not regard himself as bound by the rule and simply discerns a signal that the rule is considered obligatory by those persons in the legal system. On Waluchow's view, the disinterested observer identifies a characteristic that all legally obligatory norms might share but this characteristic cannot explain the binding force of the legal obligation.

7 Waluchow, "Lessons from Hart", Problema, n. 5, 2011, p. 380. 
To understand the binding force of a legal obligation, one must consider the attitude of someone who takes the internal point of view towards the legal system - "that is from the point of view of one who views the rule as actually providing him and others with sound or valid reasons for action." If you ask such a person why he is bound by the legal rule, he will respond that it is the importance of the value protected by the rule - and not the (formal or informal) social pressure that is authorized for violations of the rule. For someone who takes the internal point of the view toward the rule, it is the value that binds - that provides the special normative force that legal obligations provide.

\section{REPLY TO WALUCHOW}

As it turns out, Waluchow's helpful critique assumes a plausible proposition that I reject - namely, that the project of conceptual analysis of legal concepts requires, at least some of the time, that the theorist articulate the content of concepts from the vantage point of someone who takes the internal point of view towards the law. I disagree on this proposition not because I believe that the conceptual theorist must take the external point of view with respect to conceptual theorizing about law. But rather because the distinction between internal and external point of view occurs inside Hart's analysis of the relevant legal concepts.

Of course, the differences between how people view the law from the external point of view and how they view it from the internal point of view is important but these are primarily sociological questions that require empirical analysis that is no part of Hart's theory. Hart's contribution to this enterprise was to make the distinction so as to explain the concept of a social norm, among other things. But it is important to note that how people view law, legal normativity, legitimacy, and so on from a certain point of view are not conceptual issues. 
Conceptual analysis, of course, adopts an approach that presupposes something like a point of view; but it is misleading to characterize it terms of an internal or external point of view. Conceptual analysis is grounded in the language we use to impose a conceptual framework on the world, and hence is grounded in something like conventions governing language. But there does not seem to be a distinction between an internal point of view towards a language and an external point of view. Regardless of how much English one knows or speaks, it is incorrect to say that "bachelor" means "law enforcement official." No one with any knowledge of the language of the two terms would simply report that English speakers typically regard that as incorrect. That definition is simply incorrect.

My aim was to give a conceptual analysis of the notion of "legal obligation" as it functions in all possible legal systems. There are, of course, disputes about what the appropriate methodology is: e.g., is the methodology purely descriptive or normative? These distinctions do not track the distinction between the external point of view and the internal point of view. I am an advocate of traditional conceptual methodology, and that might be a mistake, but not because I adopt an external point of view.

But Waluchow's analysis is intriguing and deserves a more focused response than the above. Waluchow argues that someone who takes the internal point of view towards a legal system or a law will view the relevant law as having binding force in virtue of the values it protects - not in terms of the authorization of coercive force.

I think there are two problems with this idea. First, someone who views the binding force of the law as explained by the importance of values it protects is having a moral reaction and is likely reporting the feeling that the law imposes a moral obligation. If you ask someone who takes the internal point of view whether the authorization of coercive enforcement mechanisms is part of what makes a law mandatory, obligatory, or something one must do (in- 
stead of merely something one should do), I would be surprised if anyone would answer "no." The authorization of coercive enforcement mechanisms is always a reason for doing what the law requires even if it is not the best reason, and it seems to be absolutely essential to the explanation of the binding force of the obligation law generates. Of course, someone who merely takes the external point of view towards the law will give the same answer.

It is important to acknowledge, of course, that many people will criticize behaviour simply because it breaks the law. But people who criticize law-breaking on this ground view the system as legitimate and the legal norm as being within the scope of law's legitimate authority. Morally legitimate authorities are commonly supposed to generate content-independent obligations to obey, but these obligations are moral in character. Accordingly, most people who criticize breaking a law simply because the law requires it are making moral assertions that presuppose the legitimacy of the legal system. But this is not a requirement of Hart's theory, and simply could not be because many people do not view laws even in a system that is generally regarded as legitimate as necessarily imposing legitimate requirements. For example, nearly half of US citizens think it is illegitimate for the state to redistribute income for the purpose of alleviating poverty

Second, if I am correct in thinking mandatory legal norms necessarily create legal obligations, as Hart seems to have, then it would have to be a conceptual truth that people in a legal system take the internal point of view towards the law. But this is false. It is clearly possible that people within a legal system take only the external point of view towards the legal system or the law and hence would reject the values the law promotes. And, indeed, Hart himself expressly acknowledges that it is not a conceptual truth that citizens take the internal point of view towards the law or the legal system.

Here it is crucial to note that if legitimate legal systems give moral reasons to obey, it is uncontroversial among po- 
litical theorists that law as such does not so much give an even prima facie moral reason to obey the law. One simply cannot presume that law as such is something that will be accepted for moral reasons. Indeed, not only did Hart deny that citizens must take the internal point of view towards the law or the rule of recognition as an essential condition for the existence of a law or legal system; he clearly pointed out that officials can take the internal point of view towards the law for any reason at all. It need not be the case that even officials take the internal point of view towards the law because they believe the content is morally acceptable. Thus, even the officials need not claim that (or even purport) that citizens have a moral reason to obey the law. The most they need claim is that they claim to have a legal reason, which under my theory, is entirely reducible to prudential reasons. 